\title{
SICK AND WEAK BUT MADE OF STEEL: LUXEMBOURGIAN OPEN-AIR SCHOOLS AND OTHER RESPONSES TO THE SPREAD OF TUBERCULOSIS AT THE BEGINNING OF THE 2OTH CENTURY
}

\author{
Irma Hadžalić ${ }^{1}$ \\ wwwen.uni.lu
}

\begin{abstract}
The first decades of the twentieth century in Luxembourg were marked by societal changes connected to the expanding steel and mining industries. As elsewhere in Europe, industrialization resulted in higher rates of immigration and a lack of adequate living conditions. Contemporaries regarded these industrialization and urbanization issues as key causes for the rapid spread of tuberculosis. The pioneers of the Luxembourgian steel company ARBED (Aciéries Réunies de Burbach-EichDudelange) then started to play a significant role in society by financing tuberculosis prevention initiatives such as the Ligue Luxembourgeoise contre la tuberculose and other health centres. Perhaps the most interesting among these prophylactic initiatives, from an educational perspective, were the open-air schools. The social context in which the anti-tuberculosis initiatives and especially open-air schools gained ground in Luxembourg is described in this paper. Mapping the landscape of health initiatives for adults (e.g. hygienic education, dispensaries, visiting nurse institutions) and for children (e.g. holiday camps, family placement, open-air schools) will provide a picture of twentieth-century Luxembourg's fight against tuberculosis. Further on, the key actors that triggered these initiatives, the ways in which they were presented to the public and the motives behind their establishment will be questioned. Fostering discipline, which is an underlying motive of the above-mentioned initiatives, in order to create a healthy economic force will also be examined.
\end{abstract}

Keywords: Industry; Luxembourg; Open-air education; Tuberculosis; Propaganda.

\section{DOENTE E FRACO, MAS FEITO DE AÇO: ESCOLAS LUXEMBURGUESAS AO AR LIVRE E OUTRAS QUESTÔES SOBRE A PROPAGAÇÃO DA TUBERCULOSE NO INÍCIO DO SÉCULO XX}

Resumo: As primeiras décadas do século XX, em Luxemburgo, foram marcadas por mudanças sociais ligadas às indústrias siderúrgicas e de mineração em expansão.

\footnotetext{
${ }^{1}$ PhD student from University of Luxembourg (Luxembourg). Contact: hadzalic.irma@gmail.com.
} 
Como no resto da Europa, a industrialização resultou em maiores taxas de imigração e falta de condições de vida adequadas. Contemporâneas, as questões de industrialização e de urbanização foram consideradas como as principais causas para a rápida disseminação da tuberculose. Os pioneiros da luxemburguesa Arbed, empresa siderúrgica (Aciéries Réunies de Burbach-Eich-Dudelange), em seguida, começou a desempenhar um papel significativo na sociedade por meio de iniciativas de prevenção da tuberculose, como a Ligue Luxemburguesa contre la tuberculose e outros centros de saúde. Talvez o mais interessante entre essas iniciativas profiláticas, de uma perspectiva educacional, sejam as escolas ao ar livre. É descrito neste artigo o contexto social em que as iniciativas antituberculose, especialmente as escolas ao ar livre, ganharam terreno em Luxemburgo Mapeando a paisagem de iniciativas de saúde para adultos (por exemplo, a educação higiênica, dispensaries, visitando instituições de enfermagem) e para as crianças (por exemplo, campos de férias, colocação familiar, as escolas open-air) irá fornecer uma imagem da luta do século XX de Luxemburgo contra a tuberculose.

Palavras-chave: Indústria; Luxemburgo; Educação ao ar livre; Tuberculose; Propaganda.

\section{The social context and the beginnings of social welfare}

Decaying, dirty, dangerous, inhabitable housing with no sanitary facilities, with insufficient light and air...This is how, in 1907, Aline Mayrisch' described the living conditions of 'many' Luxembourgers who lived in an environment that was more similar to a barn than to a human apartment. 3 The needs of the growing mining and steel industries doubled the population of the (southern) industrial parts of Luxembourg between 1890 and 1910, and the new population numbers rapidly gave rise to housing and infrastructural problems.4 Families were large and lived in tight spaces. To feed his family, a (mine) worker continued to work under all circumstances, even when suffering from tuberculosis. 5 These inadequate

\footnotetext{
${ }^{2}$ Wife of ARBED's director Emile Mayrsich and one of the most influenutal initiatiors of anti-tuberculosis activities.

3 Verein für die Interessen der Frau, 1907.

4 Fayot, 2011: 39

5 Lentz, 1934: 52: "A notre époque, en plein struggle for life, un employé ou un ouvrier - surtout lorsqu'il est chargé de famille - ne quitterait pas ses occupations pour se guérir d'une tuberculose qui commence à se manifester, s'il n'a pas la certitude que lui
} 
living and working conditions along with malnutrition and poverty ${ }^{6}$ facilitated the spread of the disease. This was also a period of big changes, a period in which Luxembourg changed from an agricultural to industrial country, a period in which 'attitudes' also needed to be changed.

In agricultural Luxembourg, peasants were scarcely aware of the benefits of hygiene for the health of an individual. In a struggle to survive, they often neglected their children, carrying more for their cattle than for their posterity. 7 The popular belief that tuberculosis was god's test and punishment and a shameful family 'stain's further accelerated the spread of the disease. Thus, the problem of preventing and curing tuberculosis was essentially rooted in the way the disease was perceived. 9 Consequently, tuberculosis prevention initiatives occurred and brought about changes in architecture, culture, economy, population growth and, most significantly, in education.

The education of adults and children and the education of adults through children emerged as the prerequisite for the disease's prevention. Its prevention required, firstly, abundant material agencies and, secondly, changes in the understanding of the benefits of hygiene. Suitably, the Luxembourgian steel company ARBED (Aciéries Réunies de Burbach-EichDudelange) and especially its founder family Mayrisch eminently contributed to the development of educational, practical and 'innovative' tuberculosis prevention initiatives through their Oeuvres Sociales. ${ }^{10}$

et les siens ne tomberont pas dans l'indigence. Il conservera son poste, son mal empirera, il infectera sa famille, ses collègues et, d'un mal bénin au début, naîtra une veritable épidémie"

6 Lorang 2009: 8; Hoffman, 2008:4

7 Lentz, 1934: 13-15 "la vie d'une vache lui (paysan) était souvent plus précieuse que la santé de ses propres enfants." [All translations are the author's]

8 Ibid., 18

9 Ibid, 26: "Nous pensons qu'il ne faut pas tant imposer (author's italics) l'hygiène, mais qu'il faut faire comprendre et admettre par les intéressés eux-mêmes qu'il y va de leur proper santé”

10 Eng.'Social Works' - a series of social works undertaken by the Mayrisch family. These are described in the booklet named 'Oeuvres Sociales' from 1922. For more information, see also Reuter, 2011 
In a short time, ARBED became a synonym for Luxembourg's economic and societal prosperity. This enormous steel company was established in 1911, as a merger of the three large steel companies (BurbachEich-Dudelange). That year was a key date in the contemporary history of Luxembourg. ${ }^{11}$ By the beginning of the twentieth century, Luxembourg was the fifth largest iron-producing nation, after the USA, Germany, Great Britain and France, ${ }^{12}$ and industry-related social works were introduced to improve the health of the Luxembourgian nation. One of ARBED's greatest contributions in a fight for healthier generations was the financing of the Ligue Luxembourgeoise contre la tuberculose.

\section{La ligue luxembourgeoise contre la tuberculose: health education through prevention activities}

Tuberculosis was Luxembourg's greatest public health challenge during the first decades of the twentieth century and its impact on the economy was the country's biggest concern. ${ }^{13}$ Even though some of the initiatives against tuberculosis were financed by the State to a certain extent, the fight against tuberculosis in Luxembourg was mostly driven by corporate and industry activities. At the time, La Ligue Luxembourgeoise contre la Tuberculose (referred to as 'the League' in this article) was the only publicly recognized institution that introduced prophylactic and educational initiatives for Luxembourgian children and adults. Their activities evolved around hygienic education through propaganda and through practical solutions for health improvements, such as sanatoria.

The League obtained official recognition in 1911 but only achieved its financial peak when Aline Mayrisch de Saint-Hubert, the wife of ARBED's director Emile Mayrisch, became actively involved in the

\footnotetext{
11 Trausch, $2000: 9$

12 Goniva, 2011:17

13 Novella, 2016: 11
} 
League's initiatives around 1919, first as a member of the board of directors and then as vice-president in 1921. ${ }^{14}$ According to its reports, the League's mission was to educate the population on hygiene through efficient and continuous anti-tuberculosis propaganda (exhibitions, conferences, brochures, posters, leaflets, etc.). The League's propaganda started in 1909 when, in order to 'enlighten the people'15, they organized an antituberculosis exhibition in Luxembourg's City Hall that attracted 20,000 people ${ }^{16}$. In the following years, they continued to spread their educational propaganda by, for example, placing anti-tuberculosis posters in railway stations in 1912. The League's propaganda activities diminished during the war period, until 1920 when the Rockefeller mission's travelling unit came to Luxembourg to show an anti-tuberculosis educational film. ${ }^{17}$ Based on the effect of many other subsequently organized exhibitions, film projections and conferences, these 'new technologies of display'18, such as photography and film, were very successful and (in Luxembourgian context) innovative educational tools.

It is probably also worth mentioning the two visits (in 1925 and in 1926) of M. Viborel, director of propaganda of the French national committee of defence against tuberculosis [Comité national de défense contre la tuberculose]. Viborel gave instruction on propaganda methods, showing a series of films that also served as an innovative tool for adults' hygiene education. Moreover, this French specialist's mission was to 'teach how to teach' so that the League, through 'improved' propaganda, could continue to educate people on hygienic measures. Also, Dr. Guérin's conference of 1929 can be considered as a great accomplishment, both for the adult education and for the promotion of the League's initiatives. ${ }^{19}$ According to

14 Ever since its foundation, ARBED gave yearly donations to the League but did not donate nearly as much as when Aline Mayrisch took an active part in it. See Ligue Luxembourgeoise contre la Tuberculose 1908-1933. Pages 13-16

15 Ligue Luxembourgeoise contre la Tuberculose, 1908-1933. Page 7.

16 Ibid.

${ }_{17}$ For more on the Rockefeller mission to Luxembourg in the interwar period, see Dittrich, 2016

18 See Herman \& Plein, 2016: 5 .

19 Dr Guérin, along with Calmette, developed the BCG vaccine. See also Ligue Luxembourgeoise contre la Tuberculose, 1908-1933 
the League's report from 1933, the purpose of these events was to powerfully enlighten the public, to create a movement of the opinion towards a fight against tuberculosis and to foster efficient propaganda in order to gather necessary funds for the anti-tuberculosis fight in the Grand Duchy. ${ }^{20}$

So, the League's activities evolved around innovative education through propaganda, while pursuing accumulation of funds. As the biggest, the most important and the only active anti-tuberculosis institution, the League was fighting for more recognition and therefore for more extensive financial support. ARBED, as its biggest donator at the time, could join and use the League's activities for its own propaganda: invest to gain. As Novella (2016:34) emphasizes, "this pervasiveness of health education and propaganda is very illuminating in regard to the nature, reasons and

Figure 1 - Sanatorium Dr. Aug. Flesch à Dudelange.

La Ligue Luxembourgeoise contre la Tuberculose, 1908-1933 ; P22.

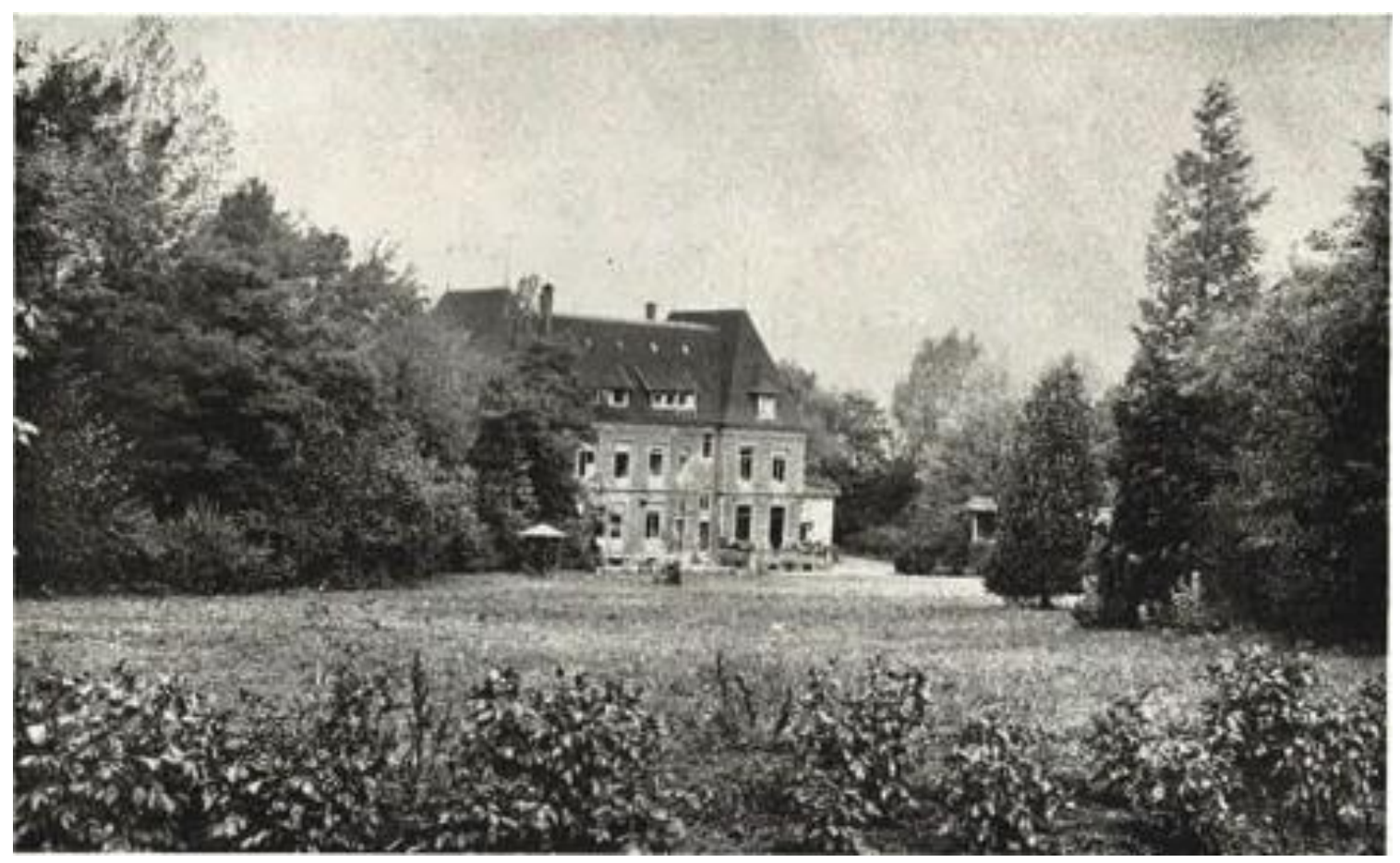

${ }^{20}$ Ibid., Page 13: « Toutes ces manifestations contribuèrent puissament à éclairer le public, à créer un mouvement d'opinion en faveur de la lutte antituberculeuse et formèrent une propagande efficace en vue de recueillir les fonds nécessaires à la lutte antituberculeuse dans le Grand-Duché » 
objectives of the thorough tuberculosis-centred sanitary offensive deployed in Luxembourg in the decades before World War II. On the one hand, the attainment of a new hygienic culture on the part of the population was seen as the shortest way to reach social peace and individual harmony, and it was often depicted as veritable utopia."

Alongside health education, the League initiated several practical solutions for the fight against tuberculosis. Dispensaries (consultation and examination centres) were created for the working class population's 'thorough educative offensive'21: three were set up in 1910 and five more in the following ten years. Dispensaries, or the so-called 'hygienic schools' for adults, were surveillance and control instruments, constituting the first practical step in the prophylactic, supervised education on hygiene of people. ${ }^{22}$ However, tuberculosis was still perceived as a shameful family disease and people were often closemouthed about it. To maintain the good family name and prevent their children from being subjected to carrier and matrimonial obstructions, many people, mostly peasants, never sought medical assistance nor declared tuberculosis as the real cause of death. ${ }^{23}$

Dispensaries were centred around three domains of action: to provide assistance and information, to educate (and therefore change the understanding of the disease) and, finally, to send patients to sanatoria where physical cures were provided. ${ }^{24}$ Indeed, most adult education on hygiene

\footnotetext{
${ }^{21}$ Novella, 2016:20

${ }^{22}$ see Rapport des délégués de la ville au Congrès de la tuberculose à Paris du 2-7 Octobre 1905, Page5.

23 Tuberculosis was more often declared as bronchitis or pneumonia. Families insisted that the doctors understate the cause of death and doctors were not entirely aware of the importance of the declaration of death caused by tuberculosis. See Lentz 1934: 7273

24 For more information on the history and functioning of Luxembourgian sanatoria, see Novella, 2016: 22-25
} 
was uniquely made possible by the League's activities. Dispensaries expanded their domain of action by setting up visiting nurse institutions. ${ }^{25}$ The task of visiting nurses was to implement League's preventive initiatives (such as information on preventive medicine, social hygiene and child protection). ${ }^{26}$ However, in spite of the great success of dispensaries and the newly established visiting nurse institutions, the League did not receive more substantial financial or moral support from the State. Even after almost 25 years of 'officially' fighting tuberculosis, the State was criticized for failing to provide sufficient support for the education on hygiene of the Luxembourgian population. ${ }^{27}$

The representatives of the League also complained that Luxembourg City's town council was systematically ignoring their work and, through their annual reports, called for the whole country to support their prophylactic and educational actions. ${ }^{28}$ Thus, the role of the State was, in fact, overshadowed by ARBED's leaders - Emile and Aline Mayrisch and their philanthropic piggy bank - whose final beneficiaries were mainly young

25 To emphasize the importance of visiting nurses, Aline Mayrisch invited Léonie Chaptal, the head of a Parisian nursing school for a conference in 1928. The first Luxembourgian visiting nurse, Mme Kauffeld, studied at Chaptal's school at the expense of Aline Mayrisch. See also Hoffmann, 2008.

${ }^{26}$ Hoffmann, 2008: 4; see also Novella, 2016

27 This becomes obvious in the following example, indicated in Lentz, 1934: 127-8: "L'Etat n'a pas le droit de se désintéresser de cette question, l'initiative privée ne dispose pas de moyens suffisants pour mener à bien une tâche d'aussi grande envergure, qui intéresse toute la nation et l'humanité entière. Nous n'ignorons pas que le Gouvernement fait depuis longtemps de louables efforts en accordant des subsides à la Ligue contre la Tuberculose, aux sociétés de secours mutuels et aux sociétés de bienfaisance; nous reconnaissons ses bonnes intentions, mais nous pensons que, s'il est très bien de combattre un incendie, lorsque les flammes ont déjà détruit la toiture, il vaut beaucoup mieux prévenir la catastrophe. Une autre tâche qui incombe à l'Etat est celle de l'éducation du public, et spécialement des enfants, en matière d'hygiène (...) Il ne suffit pas de placarder dans les endroits et les locaux publics des avis Ne crachez pas par terre, si on ne met pas à côté un crachoir utilisable. Nous l'avons déjà dit, on n'obtient pas de résultats durables en employant le mode impératif; il faut éduquer le peuple, non le contraindre à suivre des prescriptions, dont la raison d'être lui échappe trop souvent."

28 Rapport de League 1914: 32-33 
children and 10- to 40-year-olds, referred to as la force économique et reproductrice du pays. ${ }^{29}$

\section{ARBED's fresh air initiatives for children}

Figure 2 - Frame from: VU FEIER AN EISEN, reconstructed version of COLUMETA (1921/22), Courtesy of Centre national de l'audiovisuel, Luxembourg.

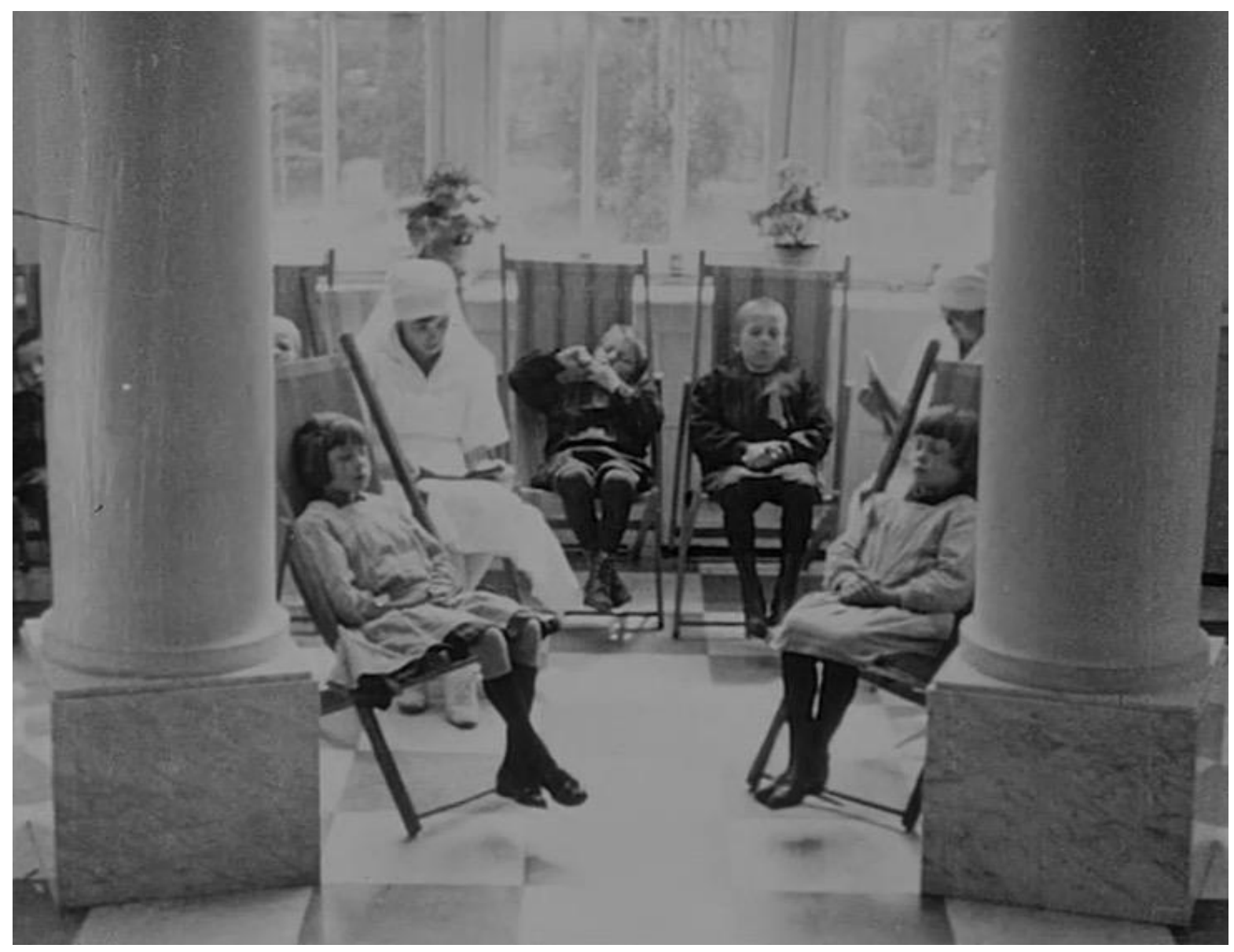

The League's prevention activities for children (e.g. holiday camps) were closely linked to those of ARBED. Prophylactic measures taken in order to 'save the nation' started by first attending to children - the future workers and citizens. Indeed, most prevention centres looked after their wellbeing. Unlike in France, where tuberculosis prevention consisted quite

29 Rapport de League 1914: 27 
frequently in placing children with rural families in less contagious and, in all respects, 'healthier' environments, or in Germany, where prevention was promoted more often in the form of open-air schools, $3^{\circ}$ Luxembourg embraced both strategies, giving children access to a variety of other prevention institutions too. Among them were holiday camps, family placement centres, children's preventorium-sanatorium (Maison des Enfants Kreuzberg) and open-air schools, all founded as a part of the social engagement of ARBED.

Like the League, ARBED also used innovative media to promote their social engagement: the preventorium, open-air schools, technical schools and other social works feature in their film COLUMETA (1921/1922) promoting the steel industry's production technologies and success as well as social works connected to and financed by ARBED. ${ }^{31}$ The children's house in Kreuzberg, the preventorium-sanatorium set up by Aline Mayrisch in Mayrisch's former villa in 1921, was the most important and only institution for the cure of tuberculosis for children younger than 14 years. ${ }^{2}$ Only children of ARBED's workers and those of the associated company Terres - Rouges were admitted to it for free.

Within the preventorium, educational action was based on acquiring knowledge about hygiene principles while helping malnourished and sick bodies to recover through strict order and supervised caloric diet.33 That is to say, discipline was at the core of this and many other initiatives created for children. The order and principles of hygiene that children acquired during their stay was also to be transmitted to their parents. The

\footnotetext{
$3^{\circ 0}$ see Connolly, 2004 ; Châtelet, 2003 \& 2011.

${ }^{31}$ COLUMETA (1921/22), directed by Gustave Labruyère and Edmund Epkens. (The restored and reconstructed version VU FEIER AN EISEN was published in 1997 by the Centre national de l'audiovisuel Luxembourg.) Besides the steel production technology and process, the film shows also the preventorium, an open-air school, farms for workers, housing projects, physical education in Institut Emile Metz, a pool for children and scouts activities.

$3^{2}$ see also Novella, 2016.

33 Preventorium is described as a « maison de plein air où ils (the children) sont soumis à un régime hygiénique avec alimentation surveillée, avec aération continue, avec repos, instruction et entraînement physique, respectivement dosés par la collaboration d'un médecin et d'un pédagogue. » (L. Bernard, CEuvres Sociales 1922: 31).
} 
preventorium was not the only children's initiative that had this double mission. Family placement initiatives, already highly popular in France, were created for very young children (aged one month - to five years old) in order to remove the potentially endangered children from contagious families. However, this initiative also had a dual goal: firstly, to save children threatened by tuberculosis in their family environment and, secondly, to introduce children to hygiene principles in rural areas. 34 Removing children from industrial cities and their possibly contagious families and placing them in fresh air - which was believed to be one of the best cures for tuberculosis, was common practice. In this way, other 'fresh air' initiatives (e.g. holiday camps and scouts' activities) started 'recruiting' sickly and poor children. In holiday camps established by ARBED and the League in 1909, children usually spent about two weeks, mostly on the Belgian coast. However, two weeks in the fresh air exposed to the sun was not enough for weak and malnourished children to regain health. At the same time, children were missing school. For this reason, open-air schools were set up.

\section{Luxembourgian open-air schools: another example of discipline and control}

It is commonly stated that Luxembourgian open-air schools were based on the German model of the allegedly first open-air school in the world, Charlottenburg (opened in 1904) ${ }^{35}$, but the French influence and,

34 Rapport de Ligue 1908-1933: 24 "L'oeuvre vise et atteint un double but: sauvegarder l'enfance menace de tuberculose, (et) introduire des notions d'hygiène infantile dans les centres ruraux. »

35 Three delegates were sent to visit the Charlottenburg open-air school and extensively reported about it in order to make plans for the first Luxembourgian open-air school. See Ewert and Urbany, 1914.; Thyssen, 2010. 
more specifically, the L'Oeuvre Grancher ${ }^{36}$ were equally important. ${ }^{37}$ Luxembourg was 'jealous' of the social works of its neighbours ${ }^{38}$ so it is not surprising that it adopted both French and German tuberculosis prevention initiatives.

The first (official) open-air school in Luxembourg opened on May $15^{\text {th }} 1913$ in the City Park Leh, two kilometres away from the industrial city of Dudelange. Dudelange school didn't have capacity to receive all the children in need of fresh air cure. The plans for the much-needed second openair school were already created in 1922 but the so-called Holzemberg school did not open until 1928, close to another industrial city, Esch-surAlzette. The Holzemberg school functioned under same principles and schedules as the Dudelange school. This time, the school was an initiative of Emile and Aline's daughter Andrée who later played an important role

${ }^{36}$ L'Oeuvre Grancher was created in 1903 by Jacques Grancher. It describes hygienic measures to be taken in order to preserve children from tuberculosis by placing them in rural areas with fresh air, away from contagious home environments. Euvre Grancher is known as the origin of the family placement idea. It was well received in France, where it was created, and then spread across Europe, including Luxembourg. The idea behind it was to spend as little money as possible to achieve the best results possible.

37 Open-air education attracted considerable international attention. Many congresses were organized to define open-air schools, conditions they need to fill, etc. The Luxembourgian Ministry of Education regularly received and kept records of open-air schools from other countries. Luxembourgers participated in the first open-air schools congress in Paris in 1922 and in the second one in Brussels in 1931 but, when invited by Karl Triebold, genereal secretary of the congress (more on Karl Triebold: see Thyssen, 2011), they refused to participate in the Third International Freiluftschulkongress in Bielefeld with the excuse: "Because of the favourable hygienic conditions of our schools there is little hope that the number of schools will increase. With such a small open-air school movement in our country, the arrival of an official (Luxembourgian) representative is hardly a question". However, almost 20 years later, Luxembourg did (again) recognize the importance of the open-air education movement and participated in the Fifth International Open-Air Education Congress in 1953 in Switzerland, acknowledging the 'leading role of open-air education in modern pedagogy'. (Archives Nationales du Luxembourg; File MEN 1652 "Ecoles en plein air 1933-1962")

38 Premier Congrès International des Ecoles de Plein Air. Paris, 1922. Page 15. In this occasion, the Luxembourgian representative Paul Mersch declared in his opening speech: "Le Luxembourg a toujours été jaloux de toutes les innovations de ses voisins au point de vue social et au point de vue de l'hygiène.” 
in social and political life in Luxembourg. 39 However, it is little known that the Mayrischs were not the sole pioneers in the Luxembourgian openair school movement (attempts).

Figure 3 - Dudelange Open-air school; 1924.

Photo: Archives de Ville de Dudelange. Fonds Jean-Pierre Conrardy.

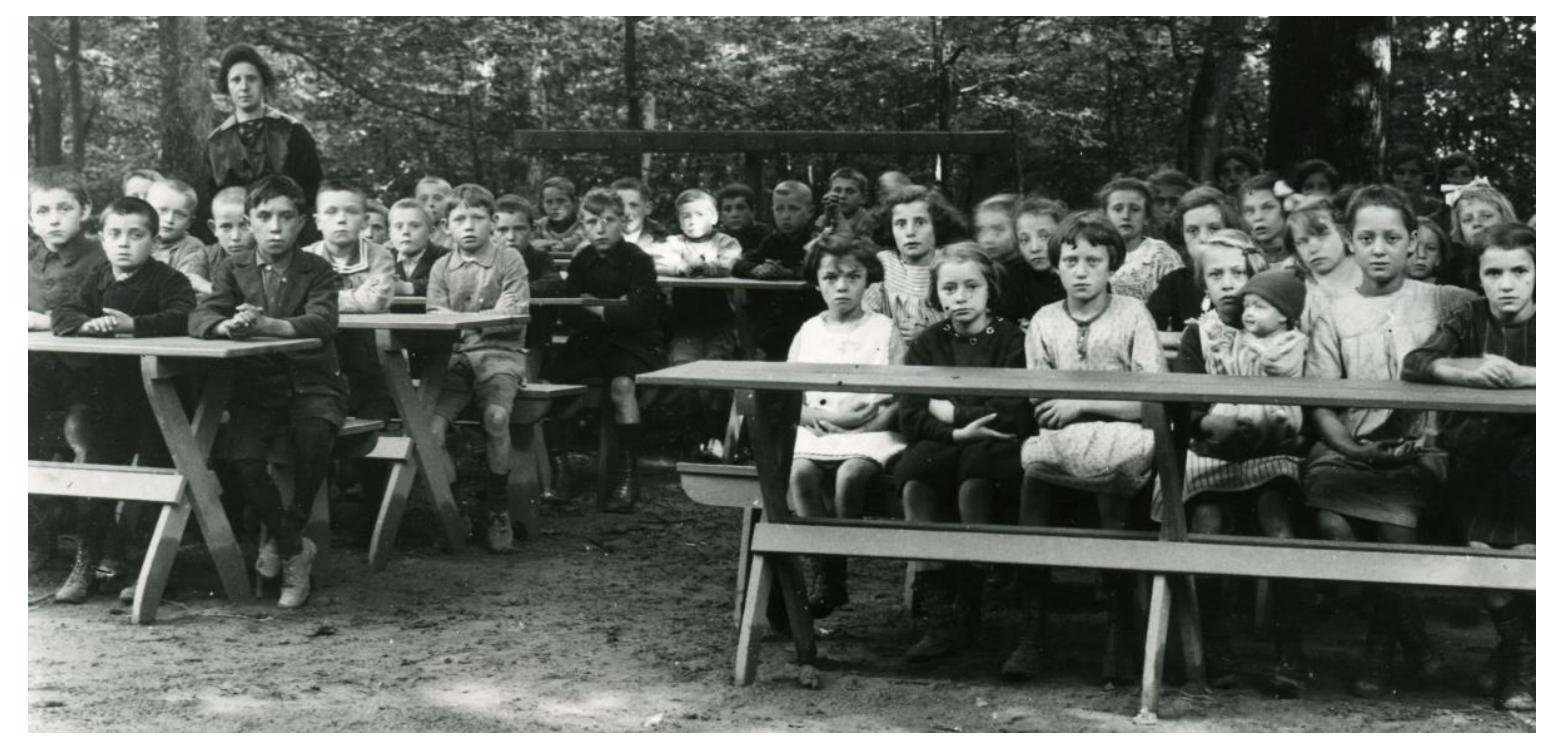

The open-air school idea came to Luxembourg, around 1909,40 when local authorities financed the so-called "Baumbusch Waldschule", ${ }^{41}$ located close to Luxembourg City and serving more as a recreational centre for the city children. Although the wish and the need to turn this centre into a real open-air school were expressed on multiple occasions, the plan was never implemented for unknown reasons. More intriguing is the fact that the local authorities of the town Tétange also started constructing an open-air school in $1929^{42}$ and, again, never finished it, probably due to financial reasons. So, the only two Luxembourgian open-air schools that existed and survived over many decades belonged to ARBED. The Mayrisch family seems to have been well aware that the future of its company (and of the country) depended on the future workers so ARBED's directors did not hesitate to invest in education and training in order to prepare the

39 Tageblatt 1948-09-02, Page 2.

40 Luxemburger Bürger Zeitung 1909-06-26, p. 2 and 1909-05-11p. 2

${ }^{41}$ Luxembourg Illustrierte Nr. $15 ; 1929$

42Tageblatt, 1930-04-25; Luxemburger Wort, 1929-10-21 
healthy and young working class. 43 As was the case for the League, the only two open-air schools in the country were, for the most part, financed by industrial stakeholders and not by the State.

What was the purpose of these open-air schools? The answer is rather simple: discipline.

As repeatedly emphasized, the first purpose of open-air schools was to improve the health of anaemic, scrofulous, rachitic, underdeveloped, nervous children and children with heart and lung diseases. Only workingclass children from Dudelange / Esch-sur-Alzette aged seven to twelve years were admitted to the schools. Younger children were considered 'too weak to attend school and better off with their families' and children older than twelve were considered 'too hard to discipline'. In the 1940s, another category of children refused admission to the schools was added: the undisciplined. 44 This category is an interesting illustration of the 'hidden' purpose of the open-air schools, which went beyond health improvement. The future working class also had to be disciplined. Those who were not disciplined by the age of twelve were not able to obtain health improvement treatment.

Be it press communication, photographs, film or official documents, open-air schools were always presented as a 'little paradise' in which children were free individuals and physically, morally and intellectually strengthened (or disciplined), enjoying their liberty through a balanced amount of work and play, rest and exercise and regularities in life conduct. Or, as school doctor and teacher emphasized in their booklet: 'It is amazing how air, sun, games, physical activity, rest and especially abundant diet work wonders to mentally and physically weakened children.' 45

\footnotetext{
43 Marx 2011: 161; Schmitz, 2011: 120

44 Categories such as children with epilepsy, chorea or ozena as well as children with urinary incontinence, lice or skin disease were also added. Archives Nationales du Luxembourg; File MEN 1652 Ecoles en plein air 1933-1962, Organisation et programme des cours de l'Ecole en forêt de Dudelange ; été 1946

45 Ewert \& Urbany, 1914: 38
} 
These schools are often initially described in a very romantic way ${ }^{46}$ but the official programs of open-air schools reveal the discipline and control that prevailed in every moment of the children's day. As a daily routine, children underwent detailed examinations of their height, weight and lung capacity. Perhaps the best way of understanding the discipline that children were subjected to, behind the fences of their little paradise, is to look at the school timetables that did not change much in the 50 years documented. 47 Every minute of time spent in forest schools was well calculated and monitored. The schedule was shaped by the popular belief that fresh air, sun and abundant food were the cure for pre-tubercular children. Having made health improvement their first purpose, open-air schools relegated academic instruction to secondary place. As indicated in the official school program, forest schooling was committed to helping children to keep up with their former class in order to re-enter the school community. Because open-air school was held during the spring and summer months (May to September/October), it was considered that the majority of the necessary curricula instruction had already been covered in the children's respective primary schools and, therefore, the school curricula was

${ }^{46}$ The school is located deep in a marvellous oak forest with the sun sweeping over it from morning until evening; none of the world's noises intrude the area sprinkled with sand and surrounded by colourful flowerbeds. A drinking fountain, a carousel, a sand pit, swings and a variety of toys make the children happy. The school hall is spacious and light, resting benches comfortable and placed in a spacious relaxation room protected from winds and storms. Paraphrased from: Tageblatt 1918-06-27. Page 1

47 Children would start their day (Monday to Saturday; on Sundays children spent less time at school and mostly that day was reserved for a walk in nature and games) at around 7:30 a.m. After breakfast they had around two hours of French, German or Mathematics. After lessons they had their second meal (collation) followed by recreational games, walks or singing and drawing lessons. These were followed by a $40-\mathrm{mi}-$ nute lesson (again French, German or Maths) and then respiratory exercises and gymnastics. Noon was reserved for lunch after which children had to do a siesta for almost two hours. The afternoon, after the siesta, was reserved for sunbathing, gymnastics, games or religion classes and another collation. After the second collation some time was reserved for recreation and games, followed by dinner, and finally they left school around 7:00 p.m. Of almost 12 hours spent in school, children ate five times, slept for two hours, had curricula instruction for three hours and the rest of the time was spent with recreation games and physical exercises. See Archives Nationales du Luxembourg; File MEN 1652 "Ecoles en plein air 1933-1962" \& File IP1438 "Ecoles en plein air, 1913-1933" 
halved, 'limited to the most important subjects' because "teaching/instruction has to take into account firstly the health condition of children." 48

Average weight gain (around $2.3 \mathrm{~kg}$ per child) was described as the result obtained in the open-air schools. To achieve this, children were (over)fed five times a day. The school doctor's report indicates that the caloric value of food always exceeded the demand; the diet was based on carbohydrates and fats to achieve physical strength and weight gain. 49 However, academic achievements, in spite of the reduced curriculum, are also often emphasized as a means of highlighting the dedication of the school's employees. Dr. Urbany stated in his report from $1919^{50}$ that the children attending the forest school were in no way behind their school mates from other schools, explaining how these results were achieved: "That result is due to the considerable dedication and pedagogical capacities of the teaching staff but the influence of sanitary and hygienic measures on these results is incontestable and illustrates what the Latin proverb says: mens sana in corpore sano."

Evidently, conformism to rules and strict control was hidden behind the image of freedom portrayed to the outside world. The contrast between controlled repetitive daily practices such as eating, sleeping, playing, exercising on the one hand and their depiction as an educational ideal is questionable. One thing is sure: the need for fresh air and for the tuberculosis stall changed the educational purpose, content and space in Luxembourgian open-air schools. The only ones who successfully introduced these changes were those in charge of the country's economic prosperity. However, 'healing the nation' was not the sole purpose of the industrial philanthropy.

\footnotetext{
48 Archives Nationales du Luxembourg; File MEN 1652 "Ecoles en plein air 1933-1962" Organisation et programme des cours de l'Ecole en forêt de Dudelange ; été 1939

49 Koerperich, L. et al. (1980-1982:106)

$5^{\circ}$ Archives Nationales du Luxembourg, File IP1438 "Ecoles en plein air, 1913-1933"
} 


\section{The final response: industrial and social welfare}

The new challenges Luxembourgian society had to face at the beginning of the twentieth century and the changes those challenges caused had been so far discussed. It became apparent that the pioneers of the growing industry came to play an important role by financing the tuberculosis prevention centres. One family in particular - the Mayrischs - used their resources to finance and set up centres for the hygiene education of adults (e.g. La Ligue Luxembourgeoise contre la tuberculose, dispensaries, visiting nurse institutions, sanatoria) and children (holiday camps, family placement centres, preventorium, open-air schools) in order to 'save' the Luxembourgian nation51. By examining the example of open-air schools, it became apparent that children's' health improvement was not the sole goal of the industrial philanthropy. Disciplining the future generation of the workforce was one of the greatest motives of the health-improvement initiatives. As Novella (2016:9) puts it, "industry-related entrepreneurship in the domain of tuberculosis prevention and treatment was essentially inspired by educational conceptions, and more particularly, by the goal of creating new patterns of subjectivity and citizenship for the country's working class."

ARBED expressed its pride in its social works in a variety of media. It widely distributed promotion materials (booklets, photographs, film) promoting the betterment in health care, hygiene and living conditions. These were published in different languages and displayed at local and international exhibitions. Photographs of open-air schools and of the Mayrisch Villa, which had been transformed into a children's preventorium, were largely distributed as postcards..$^{2}$ It is not accidental that the initiatives for children were most frequently depicted; attending to children first was a logical move. With their anti-tuberculosis initiatives, the Mayrischs were the pioneers of social initiatives in Luxembourg. Other

${ }^{1}$ To know more about the role of open-air schools in forming the identity and citizenship, see Thyssen, 2015 \& Châtelet, 2003 $5^{2}$ see also Lorang $2009: 70$ 
than pure philanthropy, what were the motives of these industrialists? Their social initiatives served as a tool for the company's propaganda, helped ensure the economic force of the growing industry and, as Herman (2014:611) emphasized, industrialists could intervene without being accused of acting in their own self-interest.

To educate and discipline the future generation of workers could have only been beneficial to the company. While helping children, they could obtain the workers' loyalty and attachment to the company.53 By adapting health initiatives to the specific conditions in the country (and more so to the specific conditions of the company's workers), the Mayrischs became the philanthropists responsible for Luxembourg's social and economic prosperity while fulfilling their own interests. 54 Or, as Schmitz (2011:150/151) put it nicely: "It goes without saying that all these measures were not set up merely to satisfy our industrialists' common philanthropic concern, but also to fulfil their own interests at the same time, in the sense that they reinforced the worker's dependence on his employer and, indeed, were supposed to prevent social and political unrest among the working class." Industry and its leaders were the drivers at the outset of social welfare in Luxembourg, for reasons other than pure philanthropy. Emile Mayrisch himself probably said it better: "Not from philanthropy, even less out of sympathy, but out of interest we have done it." 55

\section{Acknowledgments}

The author would like to thank Cláudio de Sá Machado Jr. for the invitation to contribute to this issue; Karin Priem for her valuable inputs and supervision; Geert Thyssen for sharing his expertise on open-air schools with me; Frederik Herman, Klaus Dittrich and Ira Plein for their support and comments; Claude Kugeler for facilitating access

\footnotetext{
53 See also Scuto , 2011:44

54 Wilwert, 1957: 173

55 Ger. "Nicht aus Philantrophie, noch weniger aus Mitleid, sondern aus Interesse haben wir das getan." Mayrisch, E. Das Düdelinger Economat und seine Berechtigung, Th. Schroell, Luxembourg, 1906, p.14, in Schmitz 2011 :153
} 
and offering valuable materials in the Dudelange Archives; and Amanda Habbershaw for editing and proofreading this article.

\section{References}

Châtelet, A.M, Lerch, D. and Luc, J.N. (Eds). L'école de plein air. Une expérience pédagogique et architecturale dans l'Europe du XXe siècle. Editions Recherches

Châtelet, A.M. 2011. Le Souffle du Plein Air. Histoire d'un projet pédagogique et architectural novateur (1904-1952). Metiss Presses; Genève

Connolly, C. 2004. Pale, poor, and 'pretubercular' children: a history of pediatric antituberculosis efforts in France, Germany, and the United States, 1899-1929. Nursing Inquiry 2004; 11(3): 138-147

Dittrich, K. 2016 (forthcoming) Fighting Against the Hereditary Enemy of Mankind: The Rockefeller Foundation and the Struggle against Tuberculosis in Interwar Luxembourg

Ewert, J. \& Urbany,A. 1914. Die Waldschule der Stadt Düdelingen : gegründet 1913 durch die Vereinigten Hüttenwerke Arbed, Abteilung Düdelingen ; Einrichtung und Organisation im ersten Jahre ihres Bestehens. Luxemburg : Gustave Soupert

Fayot, B. 2011. Merci au "Minettsdapp"! Forum, No. 304. February 2011. Grancher, J. 1904. Préservation scolaire contre la tuberculose. Par M le professeur Grancher. Paris, Imprimerie typographique Jean Gainche.

Goniva, J. 2011. The emergence of modern steelmaking in the $19^{\text {th }}$ century. In La sidérurgie luxembourgeoise: un siècle d'histoire et d'innovation. Steelmaking in Luxembourg : a century of history and innovation. ArcelorMittal, Luxembourg

Herman, F. 2014 Forging harmony in the social organism: industry and the power of psychometric techniques. History of Education, 43:5, 592614

Herman, F. and Plein, I. 2016 (forthcoming). Envisioning the Industrial Present: Pathways of Cultural Learning in Luxembourg (1880s-1920s) Hoffmann, M. 2008. Le développement du travail social au Luxembourg à travers l'activité centenaire de la Ligue médico-sociale. Publié par La Ligue médico-sociale. 
Koerperich, Léon; Krantz Robert; Conrardy Jean-Pierre. (1980-1982) Düdelinger Chronik. Band II. 75 Jahre Stadt Düdelingen 1907 -1982. 100 Jahre Düdelinger Hütte 1882-1982. Düdelingen : s.n.

Lentz, J.J. 1934. La Lutte contre la tuberculose dans le Grand Duché de Luxembourg. Luxembourg, Imprimerie de La Cour Joseph Beffort.

Ligue Nationale Luxembourgeoise contre la tuberculose. 1914. Rapport moral, médical et financier sur l'exercice 1913.

Ligue Luxembourgeoise contre la tuberculose 1908-1968.

Ligue Luxembourgeoise contre la tuberculose 1908-1933. 25 Années de Lutte Antituberculeuse dans le Grand-Duché de Luxembourg.

Lorang, A. 2009. L'image Sociale de l'Arbed à travers les collections du Fonds de logement. Le fonds pour le développement du logement et de l'habitat; Luxembourg

Marx, J. 2011. ARBED, a pioneer of professional training in Luxembourg. In La sidérurgie luxembourgeoise: un siècle d'histoire et d'innovation. Steelmaking in Luxembourg : a century of history and innovation. ArcelorMittal, Luxembourg

Novella, E. 2016. (forthcoming). Tuberculosis and Political Economy: Industrial Wealth and National Health in the Grand Duchy of Luxembourg, c. 1900-1940.

Oeuvres Sociales. 1922. ARBED (Aciéries reunites Burbach-EichDudelange)

Rapport des délégués de la ville au Congrès de la tuberculose à Paris du 27 Octobre 1905. Imprimerie Ch. Praum

Reuter, A. 2011. Migrations, society, mentalities. In La sidérurgie luxembourgeoise: un siècle d'histoire et d'innovation. Steelmaking in Luxembourg : a century of history and innovation. ArcelorMittal, Luxembourg Schmitz, N. 2011. Le patrenalisme d'Emile Mayrisch. In Terres rouges. Histoire de la sidérurgie luxembourgeoise. Centre d'études et de recherches européennes Robert Schuman. Archives nationales de Luxembourg

Schmitz, N. 2011. ARBED's social policy. In La sidérurgie luxembourgeoise: un siècle d'histoire et d'innovation. Steelmaking in Luxembourg : a century of history and innovation. ArcelorMittal, Luxembourg Scuto, D. 2011. Le regard étonné d'un historien sur cent ans de relations sociales. Forum, nr 304. February 2011.

Trausch, G. 2000. L'ARBED dans la société Luxembourgeoise. Luxembourg; ARBED S.A., Corporate Communications 
Thyssen, G. 2010. The Open-Air Schools of Dudelange and Esch-surAlzette. Forum für Politik, Gesellschaft und Kultur. No 301. Pp 40-42 Thyssen, G. 2011. Mapping a space of biography: Karl Triebold and the Waldschule of Senne I-Bielefeld (c .1923-1939). History of Education, 2011, p.1-20

Thyssen, G. 2015. Engineered Communities? Industry, open-air schools, and imaginaries of belonging (c. 1913-1963) pp. 297-320. History of Education \& Children's Literature X/2

Verein für die Interessen der Frau, 1907. Einiges über Wohnungsverhältnisse der ärmeren Arbeiterbevölkerung in Luxembourg. Zusammengestellt vom Vorstand des "Vereines für die Interessen der Frau" und hereausgegeben in Verbindung mit dem "Verein für Volks-und Schulhygiene". Luxemburg, Druck von M. Huss 1907

Wilwert, R. 1957. La vie médicale à Dudelange depuis 19oo. L'évolution de la medicine et d'orgaisation médicale. In 1907-1957. Livre du cinquantenaire de la Ville de Dudelange. L’imprimerie Coopérative. Eschsur-Alzette.

\section{Newspapers articles}

Luxemburger Bürger Zeitung 1909-06-26, Page 2

Luxemburger Bürger Zeitung 1909-05-11, Page 2

Tageblatt 1918-06-27. Page 1

Luxemburger Wort 1929-10-21-01

Luxembourg Illustrierte $\mathrm{Nr} 15 ; 1929$

Tageblatt 1930-04-25-01

Tageblatt 1948-09-02, Page 2

\section{Archives Nationales du Luxembourg}

File IP1438 "Ecoles en plein air, 1913-1933"

File MEN 1652 "Ecoles en plein air 1933-1962"

Received in March 17, 2016. Approved in June 17, 2016. 